\title{
Epigenetic Assessment of Environmental Chemicals Detected in Maternal Peripheral and Cord Blood Samples
}

\author{
Yoshikazu ARAI ${ }^{1-3)}$, Jun OHGANE ${ }^{1,3)}$, Shintaro YAGI ${ }^{1)}$, Rie ITO ${ }^{4)}$, Yusuke IWASAKI ${ }^{4)}$, \\ Koichi SAITO ${ }^{4)}$, Kazuhiko AKUTSU ${ }^{5)}$, Satoshi TAKATORI ${ }^{5)}$, Rie ISHII ${ }^{6)}$, Rumiko HAYASHI ${ }^{7}$, \\ Shun-Ichiro IZUMI ${ }^{8)}$, Norihiro SUGINO ${ }^{9)}$, Fumio KONDO ${ }^{10)}$, Masakazu HORIE6), \\ Hiroyuki NAKAZAWA ${ }^{4)}$, Tsunehisa MAKINO ${ }^{11)}$ and Kunio SHIOTA ${ }^{1)}$
}

\begin{abstract}
${ }^{1)}$ Laboratory of Cellular Biochemistry, Animal Resource Sciences/Veterinary Medical Sciences, The University of Tokyo, Tokyo 113-8657, 2) Laboratory of Developmental Engineering, Department of Life Science, School of Agriculture, Meiji University, Kawasaki 214-8571, ${ }^{3)}$ Laboratory of Genomic Function Engineering, Department of Life Science, School of Agriculture, Meiji University, Kawasaki 214-8571, ${ }^{4)}$ Department of Analytical Chemistry, Faculty of Pharmaceutical Sciences, Hoshi University, Tokyo 142-8501, ${ }^{5)}$ Division of Food Chemistry, Osaka Prefectural Institute of Public Health, Osaka 537-0025, '6) Saitama Prefectural Institute of Public Health, Saitama 338-0824, 7) Department of Toxicology, Aichi Prefectural Institute of Public Health, Nagoya 462-8576, ${ }^{8)}$ Department of Obstetrics and Gynecology, School of Medicine, Tokai University, Kanagawa 259-1193, 9) Department of Obstetrics and Gynecology, Yamaguchi University Graduate School of Medicine, Ube 755-8505, ${ }^{10)}$ Department of Pharmacology, School of Medicine, Aichi Medical University, Aichi 480-1195 and ${ }^{11)}$ Toubu Hospital, Shizuoka 412-0041, Japan
\end{abstract}

\begin{abstract}
Epigenetic alteration is an emerging paradigm underlying the long-term effects of chemicals on gene functions. Various chemicals, including organophosphate insecticides and heavy metals, have been detected in the human fetal environment. Epigenetics by DNA methylation and histone modifications, through dynamic chromatin remodeling, is a mechanism for genome stability and gene functions. To investigate whether such environmental chemicals may cause epigenetic alterations, we studied the effects of selected chemicals on morphological changes in heterochromatin and DNA methylation status in mouse ES cells (ESCs). Twenty-five chemicals, including organophosphate insecticides, heavy metals and their metabolites, were assessed for their effect on the epigenetic status of mouse ESCs by monitoring heterochromatin stained with 4',6-diamino-2-phenylindole (DAPI). The cells were surveyed after 48 or $96 \mathrm{~h}$ of exposure to the chemicals at the serum concentrations of cord blood. The candidates for epigenetic mutagens were examined for the effect on DNA methylation at genic regions. Of the 25 chemicals, five chemicals (diethyl phosphate (DEP), mercury $(\mathrm{Hg})$, cotinine, selenium (Se) and octachlorodipropyl ether (S-421)) caused alterations in nuclear staining, suggesting that they affected heterochromatin conditions. $\mathrm{Hg}$ and Se caused aberrant DNA methylation at gene loci. Furthermore, DEP at $0.1 \mathrm{ppb}$ caused irreversible heterochromatin changes in ESCs, and DEP-, Hg- and S-421-exposed cells also exhibited impaired formation of the embryoid body (EB), which is an in vitro model for early embryos. We established a system for assessment of epigenetic mutagens. We identified environmental chemicals that could have effects on the human fetus epigenetic status.
\end{abstract}

Key words: DNA methylation, Embryoid body, Epigenetic mutagens, ES cells, Heterochromatin

(J. Reprod. Dev. 57: 507-517, 2011)

M any chemicals have been widely used in the household, agricultural and urban environment, and there are various environmental chemicals in the fetal growth environment: organophosphate insecticides (chlorpyrifos), perfluorooctane sulfonate (PFOS), di(2-ethylhexyl)phthalate (DEHP), elements of tobacco smoke (nicotine and cotinine) and heavy metals (lead $(\mathrm{Pb})$, cadmium (Cd) and mercury (Hg)) [1-5]. Hg exposure occurs in the daily intake of rice in China [6]. Prenatal exposure to environmental chemicals such as organophosphate insecticides, tobacco smoke, heavy metals and perfluorinated compounds (PFCs) is associated with fetal growth restriction and low birth weight of

Received: March 11, 2011

Accepted: April 13, 2011

Published online in J-STAGE: May 23, 2011

(C)2011 by the Society for Reproduction and Development

Correspondence: K Shiota (e-mail: ashiota@mail.ecc.u-tokyo.ac.jp) infants [7-10]. The concentration of chemicals detected in the fetal environment is, however, relatively low (around 0.1-10 ppb level) and far from the levels reported in pharmacological studies. Such a low concentration may accumulate in the fetus and placenta and affect fetal growth [11-14], and alternatively, some chemicals may have long-term effects on gene functions and stability even at a low concentration without accumulation in fetal tissues and the placenta $[15,16]$.

Epigenetic alterations have become an emerging paradigm responsible for irreversible phenotypic change through long-term gene regulation. The epigenetic marks such as DNA methylation, histone modifications and heterochromatin/euchromatin cause dynamic change of cellular conditions and cell types [17-19]. In mammals, heterochromatin, a highly condensed structure of chromatin, is characterized by DNA hypermethylation and histone modifications such as Histone H3 lysine 9 and lysine 27 (H3-K9 
and -K27) methylation [20-22]. Pericentric regions of chromosomes involve major satellite repeats forming constitutive heterochromatin [23]. Heterochromatin can be visualized by nuclear staining with 4',6-diamino-2-phenylindole (DAPI) in mouse cells. Chemical-induced epigenetic alterations in cell nuclei may be visualized by nuclear staining with DAPI as well as major satellite repeats.

There are a large number of tissue-dependent and differentially methylated regions (T-DMRs) in the mammalian genome [24-26]. Embryonic stem cells (ESCs) established from the inner-cell mass have an ability for pluripotency, which is critical for mammalian development. The profile of T-DMRs - termed the 'DNA methylation profile'-is distinctive in every cell type, including ESCs and somatic cells [25, 27]. Study of the DNA methylation profile of ESCs and somatic cells showed the existence of thousands of TDMRs that are hypo- and hypermethylated in ESCs (ES hypo hyper T-DMRs) [24]. Thus, an adequate DNA methylation profile during self-renewal and differentiation is critical for pluripotency. Recently, enrichment of short interspersed elements has been observed as a genomic property of regions harboring hypomethylated T-DMRs in ESCs [28]. Therefore, DNA methylation and heterochromatin signals will be useful for epigenetic assessment.

Chemicals that cause alterations in epigenetic systems are called epimutagens [29]. A DNA demethylating agent, 5-azacytidine, which is a cytidine analog, is a well-established epimutagen that causes reactivation of silenced genes [30]. It is known that Trichostatin A (TSA), an inhibitor of histone deacetylases, causes alteration in epigenetic regulation and nuclear structure of cells [31]. Common chemicals in the environment also cause epigenetic alteration. We previously demonstrated that dimethyl sulfoxide (DMSO), which has been used as a cryopreservant for various cell lines, altered the DNA methylation status in both gene areas and condensed repetitive sequences during the differentiation of ESCs into embryoid bodies (EBs) [32]. Carcinogenic nickel compounds have also been reported as an epigenetic modifier that induces histone methylation and changes in gene expression and chromatin structure [33]. Thus, environmental chemicals may have the potential to affect epigenetic states in the embryonic tissue or cells.

We report here the epigenetic effects of 25 environmental chemicals at low concentrations, which were detected in maternal peripheral blood and cord blood, on heterochromatin signals and DNA methylation status of T-DMRs in mouse ESCs.

\section{Materials and Methods}

\section{Maternal peripheral blood and cord blood samples}

Maternal peripheral blood and cord blood samples at term were collected at Yamaguchi University during 2008-2010 for analysis of 3-phenoxybenzoic acid (3-PBA), 3,5,6-trichloro-2-pyridinol (TCP), dimethyl phosphate (DMP), diethyl phosphate (DEP), dimethyl thiophosphate (DMTP), diethyl thiophosphate (DETP), perfluorooctanoate (PFOA) and PFOS (Table 1). The blood samples were collected at Tokai University during 2005-2007 for other chemicals. This study was approved by the Ethics Committee of Yamaguchi Grand Medical Center, the Yamaguchi University School of Medicine, and the Human Subjects Committee of Tokai
University Hospital. All samples were taken with written informed consent.

\section{Sample preparation and chromatography conditions}

Determination of the serum concentrations of chemicals except for organophosphate and pyrethroid insecticides (Group A), heavy metals (Group E) and volatile organic compounds (VOCs; Group F) was as previously described [3, 4, 34, 35]. For octachlorodipropyl ether (S-421) (Group A), polybrominated diphenyl ethers (PBDEs; Group D) and tin (Sn; Group E), the exposure level for cells was determined by the concentrations of a nonserum sample, breast milk (S-421) and adult urine (penta-BDE [36] and Sn). The concentrations of dimethyl dithiophosphate (DMDTP), diethyl dithiophosphate (DEDTP) and deca-BDE were based on the data from previous reports [37, 38].

Determination of 3-PBA and TCP (Group A) was performed with a modified version of a previous method [39, 40] using liquid chromatography-tandem mass spectrometry (LC/MS/MS; Alliance 2695 and Quattro micro; Waters, Milford, MA, USA) equipped with an electrospray ionization probe. After addition of beta-glucuronidase for derivatization, samples were purified with an Oasis HLB extraction column (Waters) and then fractionated by reversephase chromatography on a symmetric C18 column (50 mm $\times 2.1$ mm i.d., $3.0 \mu \mathrm{m}$ film thickness; Waters) with 35\% acetonitrile and $0.1 \%$ acetic acid. Following sample loading, MS/MS was performed in negative ion mode.

For S-421 (Group A), sample preparation from human milk was performed according to the method described in Kakimoto et al. [41] with slight modifications, and the concentration of S-421 was determined by gas chromatography-mass spectrometry (GC/MS).

DMP, DEP, DMTP and DETP (Group A) were determined using the method described in Ueyama et al. [42] with some modifications. Samples were purified on a C18 cartridge column (Aisti Science, Wakayama, Japan) and then deproteinized with acetonitrile. After derivatization with pentafluorobenzyl bromide, samples were purified using a three-layer column of Florisil, PSA and anhydrous sodium sulfate. The concentrations of DMP, DEP, DMTP and DETP were determined using gas chromatography with a flame photometric detector (GC/FPD) (Agilent Technologies, Tokyo, Japan) equipped with an LVI-S200 injection port (Aisti Science) on a DB-1701 or DB-5MS column (30 $\mathrm{m} \times 0.25 \mathrm{~mm}$ i.d., $0.25 \mu \mathrm{m}$ film thickness; Agilent Technologies).

The determination of heavy metals (Group E) was performed with a modified version of a previous method [43]. Serum and urine samples were mixed with nitric acid $\left(\mathrm{HNO}_{3}\right)$ in a Nano-Band MV (GL Science, Tokyo, Japan) overnight. After microwave digestion, samples were mixed with internal standard (scandium (Sc), yttrium (Y), iridium (Ir)) and subjected to analysis by inductively coupled plasma-mass spectrometry (ICP/MS; Agilent Technologies 7500i).

VOCs (Group F) in serum samples were determined using a previously described procedure [44]. Samples were diluted with saturated saline solution and spiked with internal standard (toluene$\mathrm{d}_{8}$ ) in a CV-22 vial (Chromacol, Trumbull, CT, USA). VOCs were determined by AUTO MASS SYSTEM II (JEOL, Tokyo, Japan) coupled with Tekmar 7000 Headspace Autosampler (Teledyne 
Table 1. List of chemicals detected in serum of pregnant mothers and cord blood

\begin{tabular}{|c|c|c|c|c|c|c|c|c|c|}
\hline \multirow[b]{2}{*}{ Group } & \multirow[b]{2}{*}{ Chemical } & \multicolumn{3}{|c|}{ Mothers' serum } & \multicolumn{3}{|c|}{ Cord blood's serum } & \multirow{2}{*}{$\begin{array}{l}\text { Exposure } \\
\text { to cells }(\mathrm{ppb}) \\
(\times 1, \times 10)^{\mathrm{e}}\end{array}$} & \multirow[b]{2}{*}{ Reference } \\
\hline & & $\begin{array}{l}\text { Mean } \pm \text { SD } \\
(\mathrm{ppb})\end{array}$ & $\begin{array}{l}\text { Detection } \\
\text { range (ppb) }\end{array}$ & $\begin{array}{l}\text { Detection } \\
\text { (\%) }\end{array}$ & $\begin{array}{l}\text { Mean } \pm \text { SD } \\
(\mathrm{ppb})\end{array}$ & $\begin{array}{l}\text { Detection } \\
\text { range (ppb) }\end{array}$ & $\begin{array}{l}\text { Detection } \\
\text { (\%) }\end{array}$ & & \\
\hline A & 3-PBA & 0.3 & 0.3 & $1 / 22(4.5)$ & $<0.2^{b}$ & $<0.2$ & $0 / 22(0)$ & $0.1,1.0$ & - \\
\hline \multirow[t]{8}{*}{ (Pesticides) } & TCP & 0.9 & 0.9 & $1 / 22(4.5)$ & $<0.2^{\mathrm{b}}$ & $<0.2$ & $0 / 22(0)$ & $0.1,1.0$ & - \\
\hline & DMP & $8.6 \pm 4.2$ & $1.9-18.0$ & $14 / 22(63.6)$ & $4.3 \pm 3.9$ & $0.9-14.0$ & $11 / 22(50)$ & $0.1,1.0$ & - \\
\hline & DEP & $0.3 \pm 0.1$ & $0.2-0.5$ & 9/22 (40.9) & $0.28 \pm 0.1$ & $0.1-0.4$ & 3/22 (13.6) & $0.1,1.0$ & - \\
\hline & DMTP & $16.2 \pm 4.5$ & $10.6-22.2$ & 9/22 (40.9) & $0.9 \pm 0.8$ & $0.4-1.9$ & 3/22 (13.6) & $0.1,1.0$ & - \\
\hline & DETP & $7.9 \pm 3.0$ & $3.2-14.5$ & $21 / 22(95.5)$ & $2.8 \pm 1.8$ & $1.0-6.8$ & $15 / 22(68.2)$ & $0.1,1.0$ & - \\
\hline & DMDTP & $0.3^{\mathrm{a}}$ & 0.3 & $1 / 19(0.05)$ & & ND & & $0.1,1.0$ & [37] \\
\hline & DEDTP & $<0.05^{\mathrm{a}, \mathrm{b}}$ & $<0.05$ & $0 / 19(0)$ & & ND & & $0.1,1.0$ & [37] \\
\hline & S-421 & $10.3^{\mathrm{a}, \mathrm{c}}$ & $0.7-231$ & 58/58 (100) & & ND & & $0.01,0.1$ & - \\
\hline B & Nicotine & $1.6 \pm 2.6$ & $1.0-12.4$ & $33 / 51(64.7)$ & $1.4 \pm 0.57$ & $1.0-1.8$ & 2/11 (18.2) & 100,1000 & [3] \\
\hline (Tobacco) & Cotinine & $43.7 \pm 55.8$ & $0.5-177.2$ & $14 / 51(27.5)$ & 8.7 & 8.7 & $1 / 11(9.1)$ & 100,1000 & [34] \\
\hline C & PFOA & $1.5 \pm 0.6$ & $0.8-3.7$ & $40 / 40(100)$ & $1.4 \pm 0.5$ & $0.7-3.1$ & $40 / 40(100)$ & 10,100 & [35] \\
\hline (PFCs) & PFOS & $3.9 \pm 1.4$ & $1.7-9.3$ & $40 / 40(100)$ & $1.4 \pm 0.6$ & $0.5-3.0$ & $39 / 40$ (97.5) & 10,100 & [35] \\
\hline $\mathrm{D}$ & Penta-BDE & $0.017 \pm 0.01$ a, d & $0.006-0.04$ & 10/10 (100) & & ND & & $0.01,0.1$ & [36] \\
\hline (PBDEs) & Deca-BDE & $9.2^{\mathrm{a}, \mathrm{c}}$ & $1.3-31.0$ & $102 / 156(65.4)$ & & ND & & $0.01,0.1$ & [38] \\
\hline $\mathrm{E}$ & Sn & $1.02 \pm 0.51^{\mathrm{a}}$ & $0.34-2.38$ & $36 / 36(100)$ & & ND & & $1.0,10$ & - \\
\hline \multirow[t]{4}{*}{ (Metals) } & Se & $110 \pm 18$ & $75.0-147$ & $84 / 84(100)$ & & ND & & 100,1000 & - \\
\hline & Cd & $0.038 \pm 0.016$ & $0.012-0.096$ & $84 / 84(100)$ & $0.042 \pm 0.003$ & $0.005-0.072$ & $27 / 30(90.0)$ & $0.1,1.0$ & - \\
\hline & $\mathrm{Hg}$ & $0.6 \pm 0.34$ & $0.2-2.0$ & $84 / 84(100)$ & & ND & & $1.0,10$ & - \\
\hline & $\mathrm{Pb}$ & $0.3 \pm 0.12$ & $0.13-0.83$ & $84 / 84(100)$ & $0.30 \pm 0.05$ & $0.031-1.004$ & 26/30 (87.0) & $1.0,10$ & - \\
\hline F & 2-EHA & $<1.0^{b}$ & $<1.0-3.0$ & 7/38 (18.0) & & ND & & $1.0,10$ & - \\
\hline \multirow[t]{2}{*}{ (VOCs) } & 2-EH & $58.3 \pm 48.3$ & $10.0-182$ & 38/38 (100) & & ND & & 10,100 & - \\
\hline & DCB & $5.7 \pm 8.8$ & $0.9-53.0$ & 38/38 (100) & & ND & & 10,100 & - \\
\hline G & DEHP & $5.3 \pm 0.8$ & $4.1-6.0$ & $5 / 5(100)$ & $4.0 \pm 1.1$ & $2.6-5.4$ & $5 / 5(100)$ & $1.2,12$ & [4] \\
\hline (Phthalate) & MEHP & $4.3 \pm 1.5$ & $3.3-6.9$ & $5 / 5(100)$ & $6.3 \pm 5.1$ & $3.1-15.4$ & $5 / 5(100)$ & $5.0,50$ & {$[4]$} \\
\hline
\end{tabular}

ND: Not determined. -: Chemical level in samples was determined in this study. ${ }^{a}$ Concentrations determined in the previous studies using nonserum samples. ${ }^{\mathrm{b}}$ Detection limit level. c $\mathrm{c} g / \mathrm{g}$ lipids. ${ }^{\mathrm{d}}$ Sum of TrBDE-28/33, TeBDE-47, PeBDE-100, Pe-BDE-99, HxBDE-153 and HxBDE-154. ${ }^{\mathrm{e}}$ Based on the serum level $(\times 1)$ and a level tenfold that of the serum level $(\times 10)$.

Tekmar, Mason, OH, USA). Separation was accomplished with a Vocol column $(60 \mathrm{~mm} \times 0.25 \mathrm{~mm}$ i.d., $1.5 \mu \mathrm{m}$ film thickness; Supelco, Bellefonte, PA, USA). Analysis was performed in a selected ion monitoring mode and using quantification masses for each of the analytes.

\section{ESC culture and exposure of chemicals}

ESCs (J1) derived from 129 mouse were cultured on $0.1 \%$ gelatin-coated dishes with ES medium containing 15\% fetal bovine serum (FBS; Biowest, Nuaille, France), 2 mM of L-glutamine (Invitrogen, Tokyo, Japan), $100 \mathrm{mM}$ of nonessential amino acids (Invitrogen), $100 \mathrm{mM}$ of 2-mercaptoethanol (Invitrogen), $1 \mathrm{mM}$ of Na-pyruvate (Invitrogen), $50 \mathrm{U} / \mathrm{ml}$ of penicillin, $50 \mu \mathrm{g} / \mathrm{ml}$ of streptomycin (Invitrogen) and $2000 \mathrm{U} / \mathrm{ml}$ of leukemia inhibitory factor (LIF, ESGRO; Chemicon, Temecula, CA, USA) in Dulbecco's modified Eagle's medium (DMEM; Wako Pure Chemicals, Osaka, Japan). To induce formation of EBs, ESCs were transferred to bacterial Petri dishes. EBs were cultured in DMEM containing 10\% FBS (JRH, Lenexa, KS, USA), $50 \mathrm{U} / \mathrm{ml}$ penicillin and $50 \mu \mathrm{g} / \mathrm{ml}$ streptomycin.

ESCs or EBs from J1 ESCs were cultured with chemicals at the serum level concentrations or a tenfold higher level (Table 1). Selenium (Se), Cd, $\mathrm{Hg}$ and $\mathrm{Pb}$ were dissolved in $0.0025 \% \mathrm{HNO}_{3}$. Sn was diluted with $0.007 \%$ hydrochloric acid $(\mathrm{HCl})$. The other chemicals, including TSA (Sigma-Aldrich, Tokyo, Japan), were dissolved in $0.1 \%$ ethanol (EtOH).

\section{Slide preparation for heterochromatin analysis}

In the heterochromatin and DNA methylation analyses, all reagents, unless otherwise stated, were purchased from Wako Pure Chemical Industries. ESCs exposed to chemicals or their solvents were fixed with a fixing solution consisting of $\mathrm{EtOH}$ (A) and acetic acid (B) (A/B:3/1, v/v). After centrifugation and removal of the supernatant liquid, the cells were suspended with $20-50 \mu \mathrm{l}$ of the fixing solution, and then the interphase nuclei were spread onto a glass slide. Prepared glass slides were stored at $-20 \mathrm{C}$ until DAPI staining or DNA fluorescence in situ hybridization (DNA-FISH) analysis. For heterochromatin analysis with DAPI staining, the nuclei were stained with $0.5 \mu \mathrm{g} / \mathrm{ml}$ of DAPI (Dojindo, Kumamoto, Japan) for $5 \mathrm{~min}$ at room temperature and then washed in phosphate-buffered saline (PBS). The samples were mounted with an antifade medium, PermaFluor Aqueous Mounting Medium 
(Thermo Scientific, Wilmington, DE, USA).

\section{DNA-FISH}

DNA-FISH was performed using the major satellite repeat sequence, according to the previous reports [45, 46]. Probes specific to major satellite sequences in pericentric regions were labeled with biotin using Biotin-Nick Translation Mix (Roche Diagnostics, Tokyo, Japan). The interphase nuclei on a glass slide were immersed in $2 \times \mathrm{SSC}(0.3 \mathrm{M} \mathrm{NaCl}, 30 \mathrm{mM}$ sodium citrate, $\mathrm{pH} 7.0)$ for $30 \mathrm{~min}$ at $37 \mathrm{C}$ and then dehydrated with 70, 80 and 95\% EtOH each for $2 \mathrm{~min}$ at room temperature. After denaturation with $70 \%$ formamide in $2 \times \mathrm{SSC}(\mathrm{pH} \mathrm{7.0)}$ ) for $2 \mathrm{~min}$ at $70 \mathrm{C}$, the samples were dehydrated again with cold 70, 80 and 95\% EtOH each for 2 min at $-20 \mathrm{C}$. The probes were diluted to $10 \mathrm{ng} / \mathrm{ml}$ with hybridization solution (50\% formamide, $10 \%$ dextran sulfate, $50 \mathrm{mM}$ phosphate buffer in 2× SSC, pH 7.0) and then denatured for 5 min at $95 \mathrm{C}$. Denatured probe was added to the nuclear samples and incubated for $16 \mathrm{~h}$ at $37 \mathrm{C}$. The samples were then immersed in wash buffer (100 mM Tris-Cl, $150 \mathrm{mM} \mathrm{NaCl,} \mathrm{0.05 \%} \mathrm{Tween-20,} \mathrm{pH} \mathrm{7.0)} \mathrm{for} 5$ min at room temperature. Following incubation in blocking solution (100 mM Tris-Cl, $150 \mathrm{mM} \mathrm{NaCl}, 0.5 \%$ blocking regent (Roche Diagnostics), pH 7.5) for $30 \mathrm{~min}$ at $37 \mathrm{C}$, the samples were incubated with $10 \mu \mathrm{g} / \mathrm{ml}$ of biotinylated anti-streptavidin (Vector Laboratories, Burlingame, CA, USA) for $60 \mathrm{~min}$ at $37 \mathrm{C}$. After three sets of washing in wash buffer, the samples were incubated with $5 \mu \mathrm{g} / \mathrm{ml}$ of Texas Red-conjugated streptavidin (Vector Laboratories) for $30 \mathrm{~min}$ at $37 \mathrm{C}$ and then subjected to three sets of washing. Finally, $10 \mu \mathrm{g} / \mathrm{ml}$ of biotinylated anti-streptavidin was added to the samples again for $30 \mathrm{~min}$ at $37 \mathrm{C}$, and then the nuclei were counterstained with DAPI at room temperature.

\section{Immunofluorescence}

ESCs were fixed in $4 \%$ paraformaldehyde for $10 \mathrm{~min}$. After permeabilization with $0.2 \%$ Triton X-100 for $5 \mathrm{~min}$, samples were treated with blocking buffer (5\% BSA, 0.1\% Tween-20 in PBS) for $30 \mathrm{~min}$. The samples were incubated with anti-mouse heterochromatin protein 1a (HP1a, Chemicon, Temecula, CA, USA) dissolved in blocking buffer (1:500) for $45 \mathrm{~min}$ and then subjected to three sets of washing in PBS containing $0.05 \%$ Tween-20. After incubation with a fluorescent secondary antibody (anti-mouse IgGFITC conjugated, KPL, Gaithersburg, MD, USA) dissolved in blocking buffer (1:20) for $60 \mathrm{~min}$, the samples were washed again. Finally, the samples were mounted with PermaFluor Aqueous Mounting Medium containing $0.2 \mu \mathrm{g} / \mathrm{ml}$ of DAPI onto a glass slide. All reactions were performed at room temperature.

\section{Image acquisition and counting heterochromatin foci}

Image acquisition of DAPI staining (filter range: excitation of $360 \pm 40 \mathrm{~nm}$ and fluorescence of $460 \pm 50 \mathrm{~nm}$ ) and DNA-FISH using a Texas Red-labeled probe of major satellite sequences (filter range: excitation of $540 \pm 25 \mathrm{~nm}$ and fluorescence of $605 \pm 55 \mathrm{~nm}$ ) was performed using a fluorescent microscope (BZ-8000; KEYENCE, Osaka, Japan), and 5-10 visual fields were analyzed for individual samples. The exposure time of fluorescence for DAPI staining and major satellite DNA-FISH was fixed to $1 / 1.5 \mathrm{sec}$ and $1.0 \mathrm{sec}$, respectively. After deconvolution of the fluorescent image with the BZ-8000 software, the number of DAPI and major satellite signals in the nuclei was determined using the ImageJ software provided by the National Institutes of Health (http://rsb.info.nif.gov/ij/). Briefly, RGB images were first converted to 8-bit grayscale by linearly scaling min-max to 0-255. Next, the thresholds of intensity in DAPI and DNA-FISH images were decided within 79-84 and 1520 , respectively. Finally, the number of signals per nucleus $(n=30$ 80) was determined by ImageJ. Statistical analysis between solvent- and chemical-exposed cells was performed using the Wilcoxon test.

\section{Combined bisulfite restriction analysis (COBRA) assay}

Genomic DNA extraction and bisulfite conversion were carried out as previously described [26]. DNA methylation analysis was performed based on the previous finding [24] focusing on $48 \mathrm{~T}$ DMRs by COBRA assay [47].

Genomic DNA was extracted from ESCs in lysis buffer (100 $\mathrm{mM}$ Tris-Cl (pH 8.0), $5 \mathrm{mM}$ EDTA, 0.2\% SDS, $200 \mathrm{mM} \mathrm{NaCl}$ and $200 \mu \mathrm{g} / \mathrm{ml}$ Proteinase $\mathrm{K}$ ) at $55 \mathrm{C}$ for $30 \mathrm{~min}$. After treatment with PCI consisting of phenol (A), chloroform (B) and isoamyl alcohol (C) (A/B/C:50/49/1, v/v) for removal of proteins, RNase A (Roche Diagnostics) was added, and genomic DNA was purified by EtOH precipitation. Genomic DNA was digested with a restriction enzyme, Hind III (TaKaRa, Kyoto, Japan), and purified by EtOH precipitation. After denaturation of digested genomic DNA with $0.3 \mathrm{M} \mathrm{NaOH}$, sodium metabisulfite ( $\mathrm{pH}$ 5.0) and hydroquinone were added to final concentrations of $2.0 \mathrm{M}$ and $0.5 \mathrm{mM}$, respectively. The bisulfite reaction was performed on a PCR machine as follows: 20 cycles of $95 \mathrm{C}$ for $30 \mathrm{sec}$ and $55 \mathrm{C}$ for $15 \mathrm{~min}$, followed by $55 \mathrm{C}$ for $10 \mathrm{~h}$. Bisulfite-treated genomic DNA was purified with QIAquick Gel Extraction Kit (Qiagen GmbH, Hilden, Germany), desulfonated with $0.3 \mathrm{M} \mathrm{NaOH}$ at $37 \mathrm{C}$ for $15 \mathrm{~min}$ and then subjected to EtOH precipitation. Purified bisulfite-treated DNA was amplified with BioTaq (Bioline, London, UK) using specific primers for gene loci (Supplemental Table 1). Amplified PCR products were digested with Hpy CH4 IV (New England Biolabs, Beverly, MA, USA) at $37 \mathrm{C}$ for $3 \mathrm{~h}$ and then analyzed by microchip electrophoresis using an MCE-202 (MultiNA; Shimadzu, Kyoto, Japan). The DNA methylation level in the COBRA assay was calculated using the following formula: estimated methylation degree $(\%)=$ $100 \times I^{\mathrm{C}} /\left(I^{\mathrm{C}}+I^{\mathrm{CU}}\right)$, where $I^{\mathrm{C}}$ and $I^{\mathrm{CU}}$ represent the sum of the intensities of digested and undigested bands, respectively.

\section{Statistical analysis}

Statistical comparisons of the numbers of DAPI signals and sizes of DNA-FISH signals were performed using the Wilcoxon test, and those of DNA methylation and the areas of EBs were performed using the Student's $t$-test.

\section{Results}

\section{Chemical screening by heterochromatin marks}

An outline of the chemical exposure experiments is illustrated in Fig. 1. We first examined the effect of the 25 chemicals detected in maternal serum of pregnant mothers and cord blood (Table 1 , Groups A-G) by counting the number of DAPI signals colocalized 


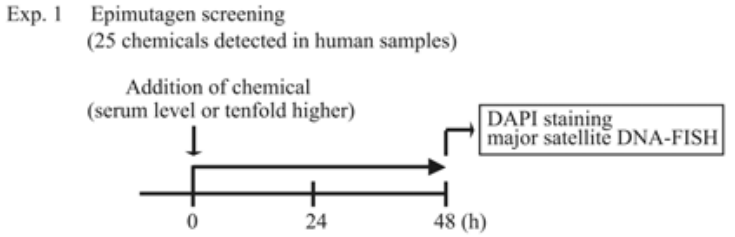

Exp. 2 DNA methylation analysis

(DEP-, Hg-, cotinine-, Se- or S-421-exposed cells)

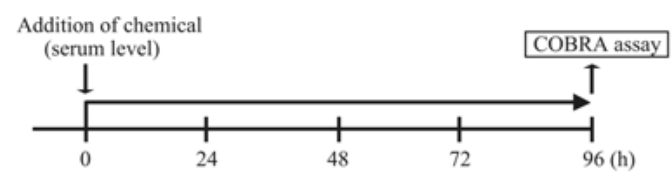

Exp. 3 Reversibility of heterochromatin changes

(epimutagen candidate: DEP, $\mathrm{Hg}$, cotinine, $\mathrm{Se}, \mathrm{S}-421$ )

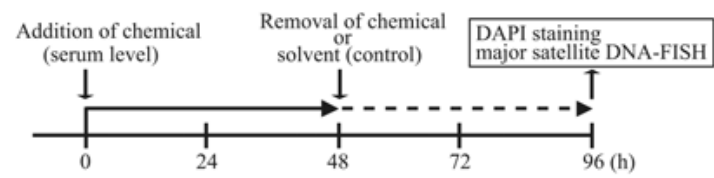

Exp. 4 EB formation

(DEP-, Hg-, cotinine-, Se- or S-421-exposed cells)

Addition of chemical
(serum level)

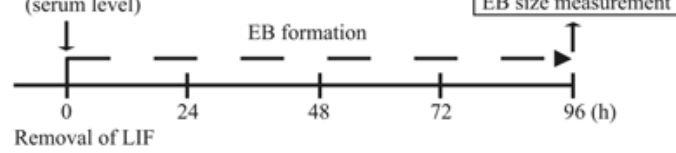

Fig. 1. Outline of the chemical exposure experiments. The scheme of the culture conditions for mouse ESCs or EBs is illustrated as Exp. 1-4. ESCs were cultured at the serum level or a level tenfold that of the serum level under stem cell conditions (+LIF) with one of the 25 chemicals that have been detected in the serum of pregnant mothers or fetal cord blood (Table 1). After 48-h exposure of cells to the individual chemicals, the heterochromatin status in the nuclei was analyzed to assess whether the chemicals have potential as epimutagens (Exp. 1) Next, to test whether chemical exposure causes alteration in DNA methylation at unique gene loci (Exp. 2) and whether or not chemical-induced heterochromatin changes are reversible (Exp. 3), we cultured ESCs with five chemicals that were determined to be epimutagens in Exp. 1. Finally, cells were exposed to chemicals at the serum level during EB formation to investigate whether the chemicals affect cellular differentiation (Exp. 4).

with signals of HP1a and major satellite DNA (Fig 2A). Reductions in the numbers were observed in ESCs treated with TSA (1.0 $\mathrm{nM})$ for $48 \mathrm{~h}$, but not with TSA at a lower concentration (0.2 nM) or with the control solvent (Fig. 2B). The other solvents, EtOH (0.1\%), $\mathrm{HCl}(0.007 \%)$ and $\mathrm{HNO}_{3}(0.0025 \%)$, in this study also had no effect on the DAPI signals in the treated ESCs (Fig. 2C).

Based on the levels of the 25 chemicals in the specimens (Table 1 , Groups A-G), we assessed the effects of the chemicals on ESCs for $48 \mathrm{~h}$ culture with each chemical at low (serum level, $\times 1$, Table 1) and high (10 times, $\times 10$, Table 1 ) concentrations (Exp. 1 in Fig. $1)$. DEP at the serum concentration $(0.1 \mathrm{ppb})$ significantly decreased the number of DAPI signals (Fig 2D). Cotinine (Group B) and $\mathrm{Hg}$ (Group E) also caused a decrease in DAPI signals at the serum concentration. In contrast, S-421 (Group A) and Se (Group E) increased the number of signals. Chemicals such as TCP, DMP, DETP and DMDTP in Group A, deca-BDE in Group D and mono(2-ethylhexyl)phthalate (MEHP) in group $\mathrm{G}$ exhibited effects on the number of DAPI signals only at high concentrations $(\mathrm{P}<0.01$; Fig. 2D). It is noteworthy that five chemicals (DEP, Hg, cotinine, Se and S-421) could affect the epigenetic status of ESCs at the concentration in the fetal environment.

\section{Effects of DEP, $\mathrm{Hg}$, cotinine, Se and S-421 on the size of heterochromatin signals}

Since decreases (DEP, Hg and cotinine) and increases (Se and S421) in the number of signals were observed by DAPI staining (Fig. 2D), we further evaluated the effects of the five chemicals (DEP, $\mathrm{Hg}$, cotinine, Se and S-421) by examining the size of the signals using DNA-FISH with major satellite repeats, in which heterochromatin signals were merged closely together with DAPI signals in all preparations and more specific to heterochromatin (Fig. 2E). The size of the heterochromatin signals by DNA-FISH was significantly decreased in Se-exposed cells $(\mathrm{P}<0.01)$, while the size showed a tendency to decrease in DEP-exposed cells (Fig. 2F). The size of the heterochromatin signal was not changed by exposure to Hg, cotinine and S-421. These data indicate that the effect of Se is distinguished from that of S-421 and that the effect of DEP can also be distinct from those of $\mathrm{Hg}$ and cotinine. These distinct reactions by the chemicals suggested that the size of heterochromatin signals should provide another dimension of heterochromatin status in addition to the number of DAPI signals and that DEP, Hg, cotinine, Se and S-421 have distinct effects on the epigenetic status of ESCs.

\section{Effects of DEP, Hg, cotinine, Se and S-421 on DNA methylation status at T-DMRs in ESCs}

To explore the effects of five chemicals (DEP, Hg, cotinine, Se and S-421) on the epigenetic status of the genome at serum level concentrations, we investigated the DNA methylation status of 48 T-DMRs of genic regions, in which the methylation degree (\%) varied from 0 to 80 in controls according to a COBRA assay using Hpy CH4 IV (Fig 3A, Exp. 2 in Fig. 1 and Supplemental Table 2).

The DNA methylation levels in the control and Hg-exposed cells were $62.2 \pm 0.79 \%$ and $72.3 \pm 2.38 \%$ at Rnd 2 T-DMR, respectively, indicating that $\mathrm{Hg}$ caused hypermethylation (Fig. 3A and 3B). The DNA methylation status at the Aebp2 and Prickle2 TDMRs was also changed, resulting in hypomethylation in Seexposed cells. The DNA methylation levels in the control and Seexposed cells were $28.0 \pm 1.04 \%$ and $18.9 \pm 0.64 \%$ at the Aebp2 TDMR and $21.5 \pm 0.70 \%$ and $16.0 \pm 0.73 \%$ at the Prickle2 T-DMR, respectively (Fig. 3B). These results indicate that $\mathrm{Hg}$ and Se affect the epigenetic status of DNA methylation as well as higher-order levels (heterochromatin) and that simple DAPI staining of ESCs enables us to screen for chemicals that affect epigenetic status.

\section{Studies on prolonged effects of DEP, Hg, cotinine, Se and S- 421}

Changes in DNA methylation, which has been regarded as a stable epigenetic mark, prompted us to assess the prolonged effects of 

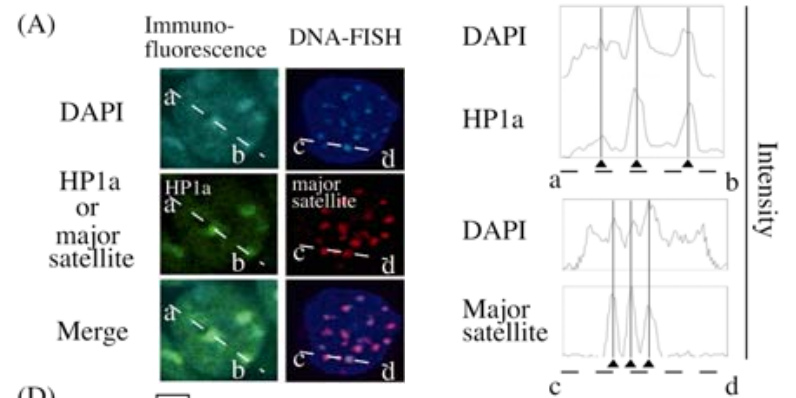

(B)

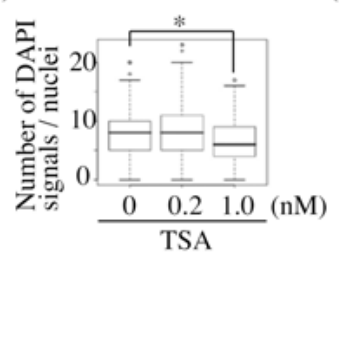

(C)

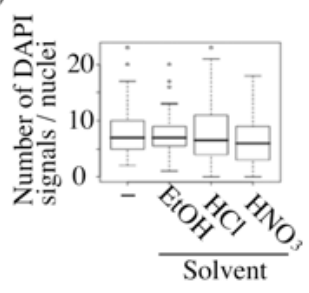

(D)

A
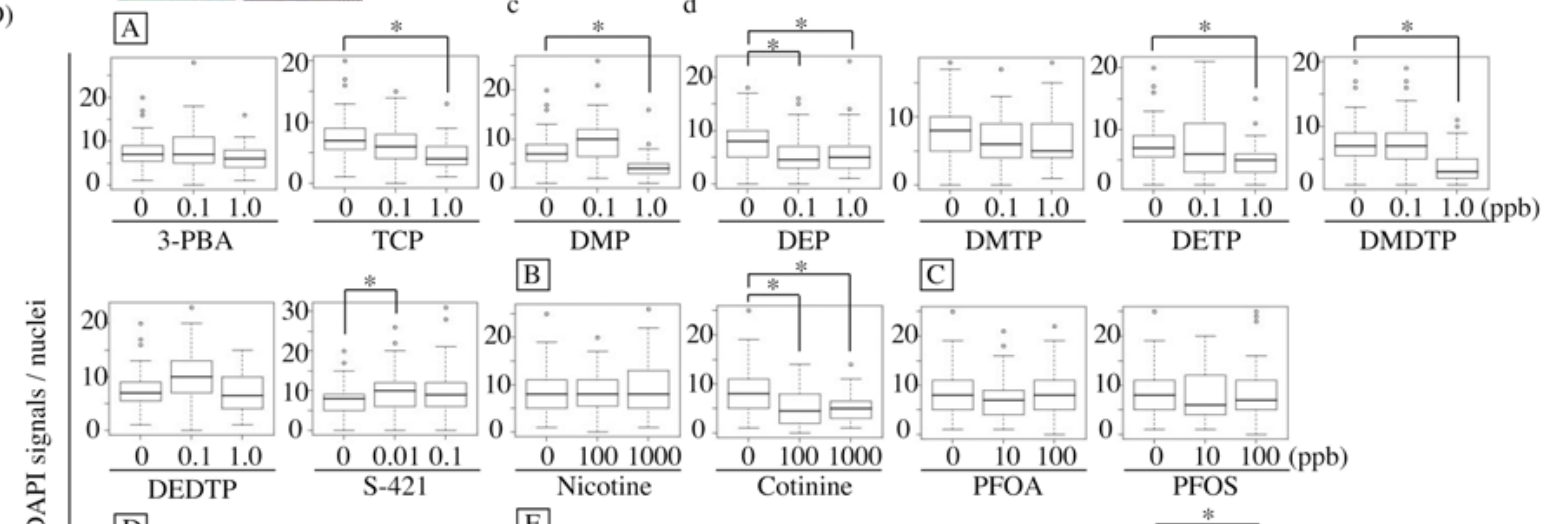

-

C

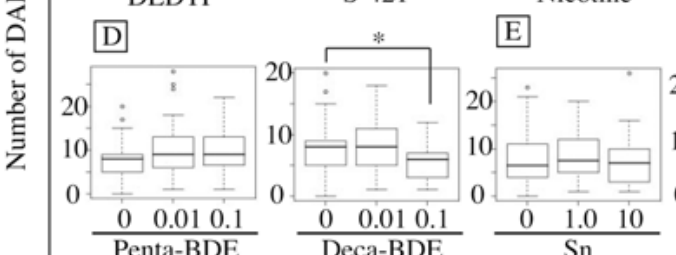
F
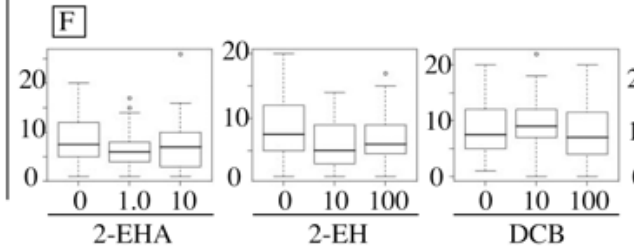

G
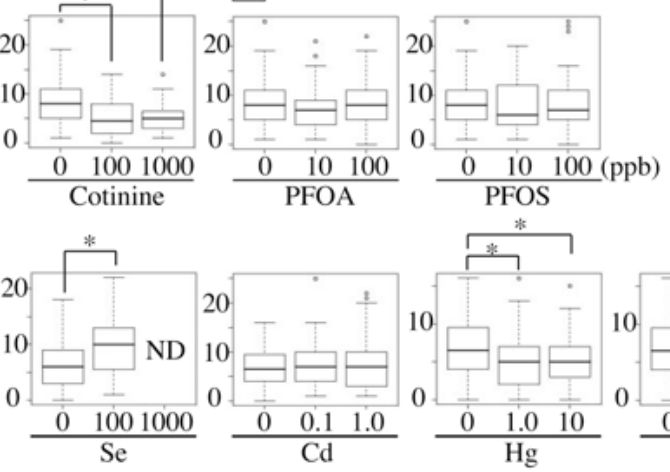

(E)

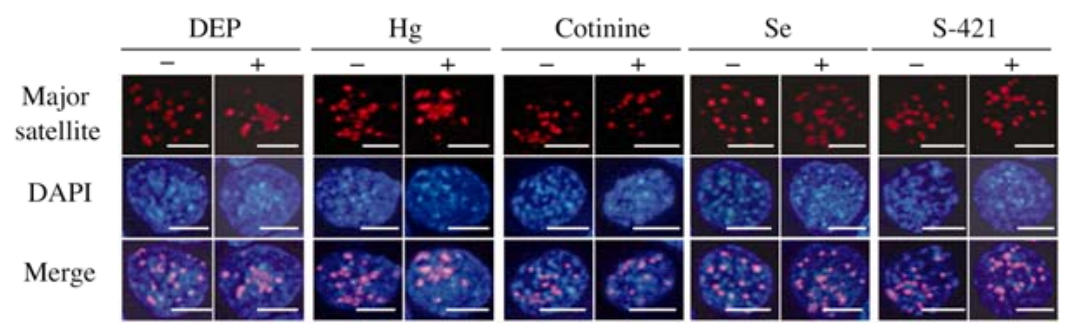

(F)
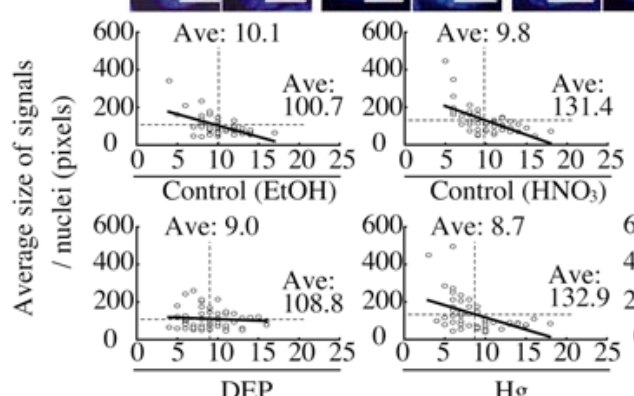

600 Ave: $8.7 \quad 600$ Ave: 9.7
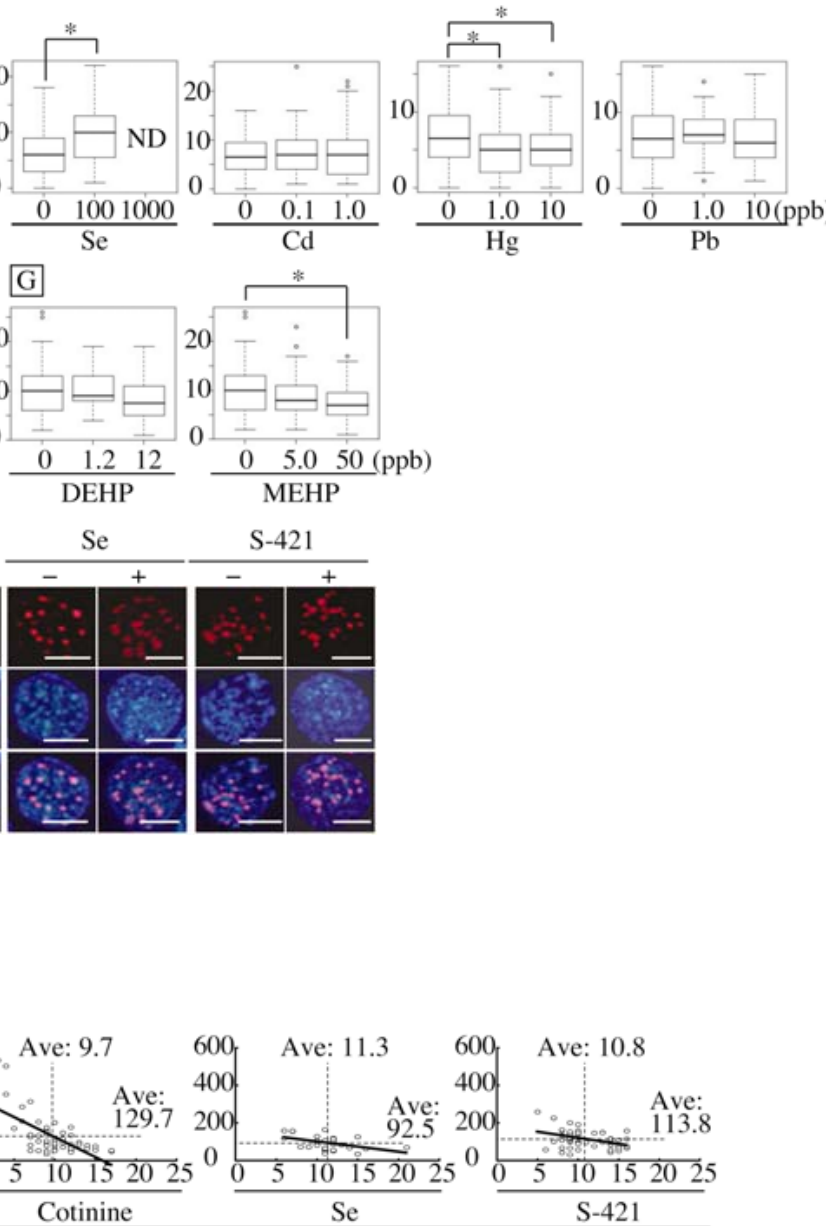

\section{Number of signals / nuclei}

Fig. 2. 
(A)
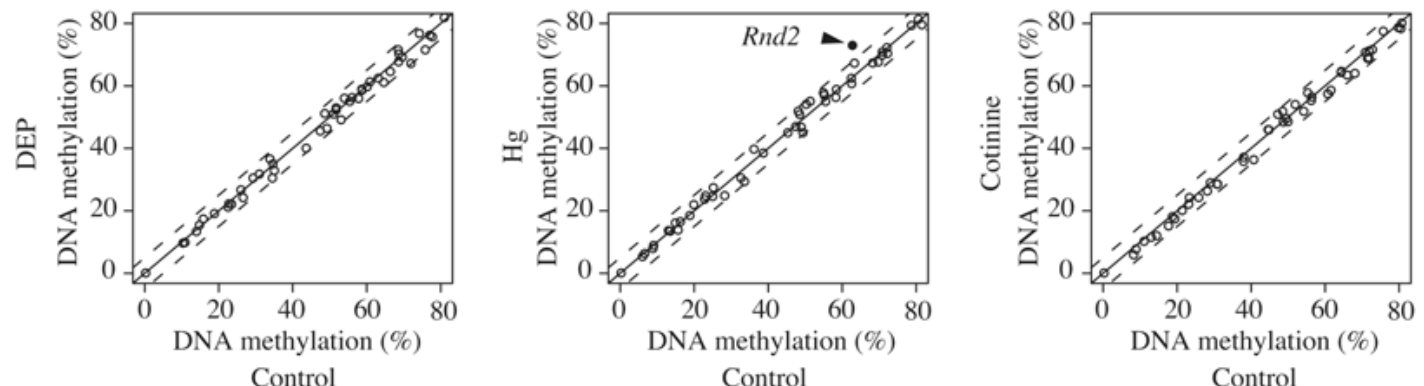

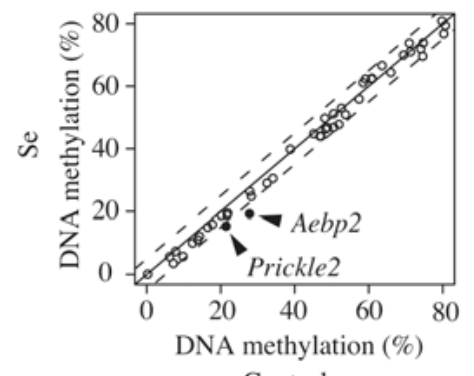

Control

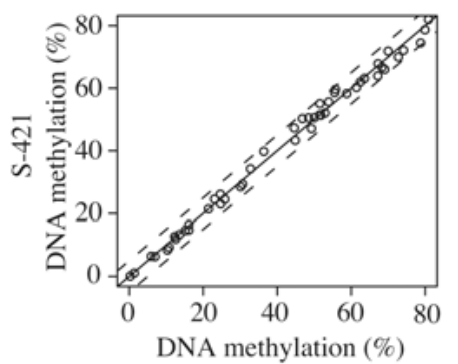

Control
(B)
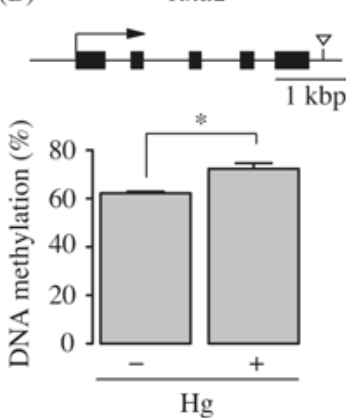

$1 \mathrm{kbp}$
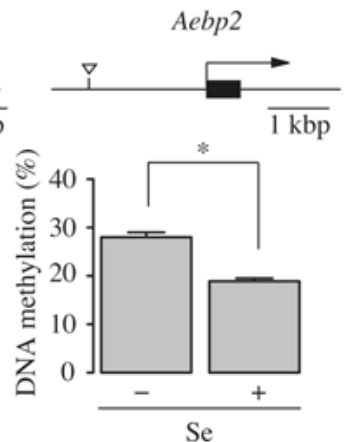

Prickle2

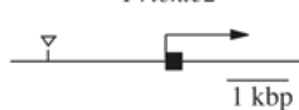

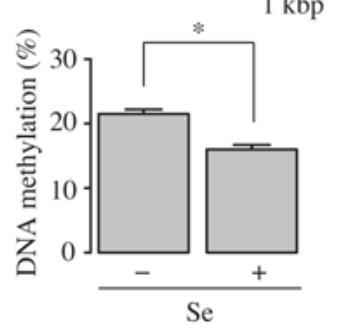

Fig. 3. Effect of chemicals on DNA methylation in ESCs. A: Analysis of DNA methylation status in chemical-exposed ESCs by COBRA assay. ESCs were cultured with chemicals (DEP, Hg, cotinine, Se and S-421) at the serum level concentrations or their solvents for 96 h. The inset indicates the workflow of COBRA. DNA methylation degree (\%) was calculated by the ratio of digested (methylated) and undigested (unmethylated) fragments. In the graph, each plot shows the methylation level of the individual gene locus that was examined. The longitudinal and horizontal axes represent the methylation level of chemical- and solvent-exposed samples, respectively. Plots that are located near the diagonal line represent similar methylation levels between chemical-exposed and solvent-treated cells. In the case of plots that are away from the diagonal line, the methylation levels are different between the two samples. Open and closed plots located inside or outside the dotted line show that the difference in the methylation level between the chemical- and solvent-exposed cells was within or over 5\%, respectively. B: Methylation status at the Rnd2, Aebp2 and Prickle2 T-DMRs by COBRA assay. DNA methylation degree (\%) is shown as the average \pm standard error (SE). Rnd2 became more methylated upon Hg exposure, and Aebp2 and Prickle2 exhibited reduced methylation degrees after Se exposure. The positions of the Hpy CH4 IV site are illustrated as triangles. Black boxes represent exons, and the first exon is only represented in the Aebp2 and Prickle2 genes. Statistical comparisons of DNA methylation were performed using the Student's $t$-test. *: $\mathrm{P}<0.01$.

Fig. 2. Establishment of an epimutagen screening method and identification of epimutagen candidates by heterochromatin staining in mouse ESCs. A: Visualization of heterochromatin structure in nuclei by DAPI staining, immunofluorescence and DNA-FISH. The signal intensities of DAPI, HP1a or major satellite on the dotted lines (a-b or c-d) were measured and plotted. The strong DAPI signals (filled triangles) were confirmed to merge with the two heterochromatin markers, HP1a and major satellite signals. B: Confirmation of altered heterochromatin by DAPI staining of mouse ESCs with a known epimutagen, TSA. After 48-h exposure of ESCs to TSA (0, 0.2 or 1.0 nM), the cells were stained with DAPI, and the number of DAPI dense signals per interphase nucleus was determined with the ImageJ software. The number of signals is shown as a box plot. Statistical comparisons of signal numbers were performed using the Wilcoxon test. *: P<0.01. C: Effect of solvent on number of DAPI signals. The numbers of DAPI signals were counted and plotted as in B. -: Without solvent. D: Number of DAPI signals in nuclei of ESCs exposed to chemicals. ESCs were cultured with chemicals that were categorized into seven groups (A-G) for $48 \mathrm{~h}$ at the serum level or a level tenfold that of the serum level. The number of DAPI signals in the nuclei was determined with the ImageJ software. Statistical comparisons of signal numbers were performed by the Wilcoxon test. *: $\mathrm{P}<0.01$. ND: Not determined; cells died of chemical exposure. E: Confirmation of heterochromatin changes in nuclei of mouse ESCs exposed to DEP, Hg, cotinine, Se or S-421 by major satellite staining. Heterochromatins in interphase nuclei were visualized by DNA-FISH with a specific probe for a heterochromatin marker, major satellite (red), and by DAPI staining (blue). Scale bar= $10 \mu \mathrm{m}$. F: Size of heterochromatin signals in nuclei of chemical-exposed ESCs. In the graph, the longitudinal and horizontal axes represent the average size and number of major satellite signals in nuclei by DNA-FISH analysis, respectively. 
(A)
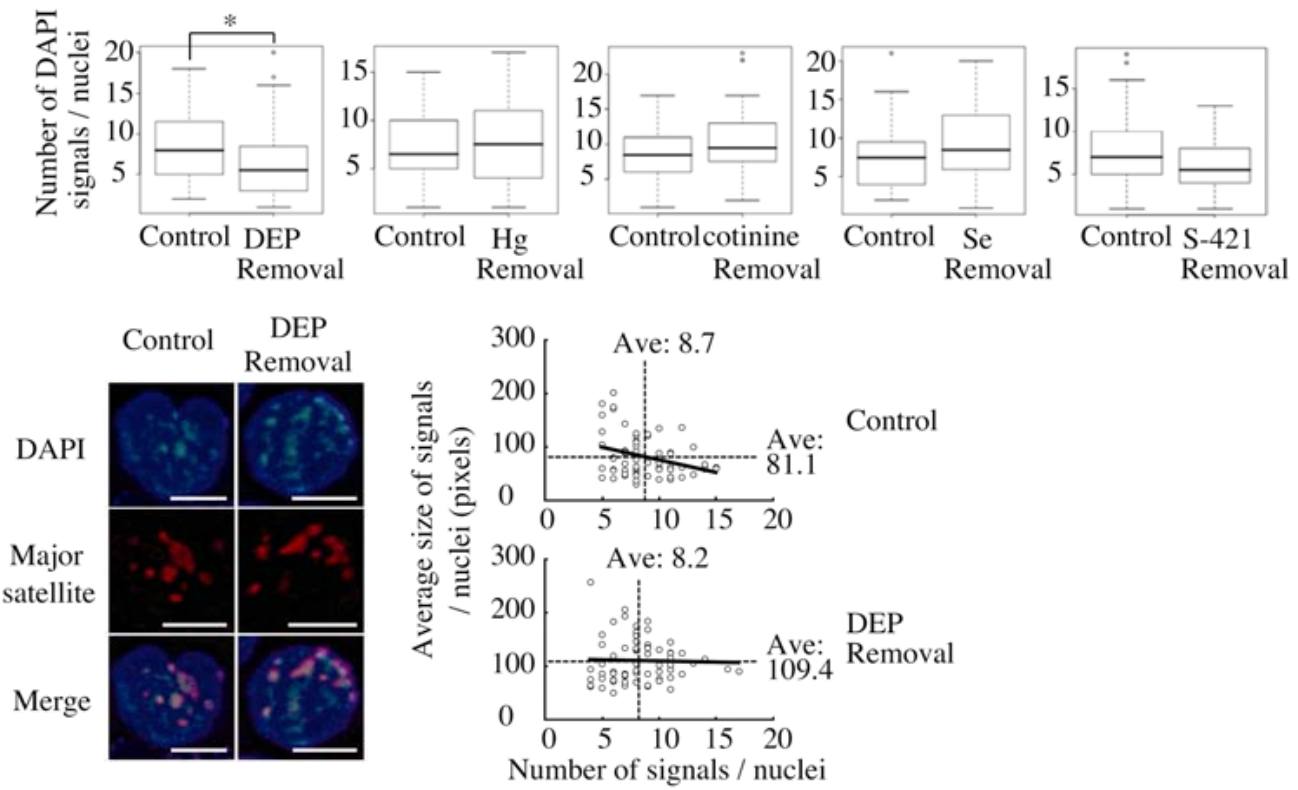

(B)

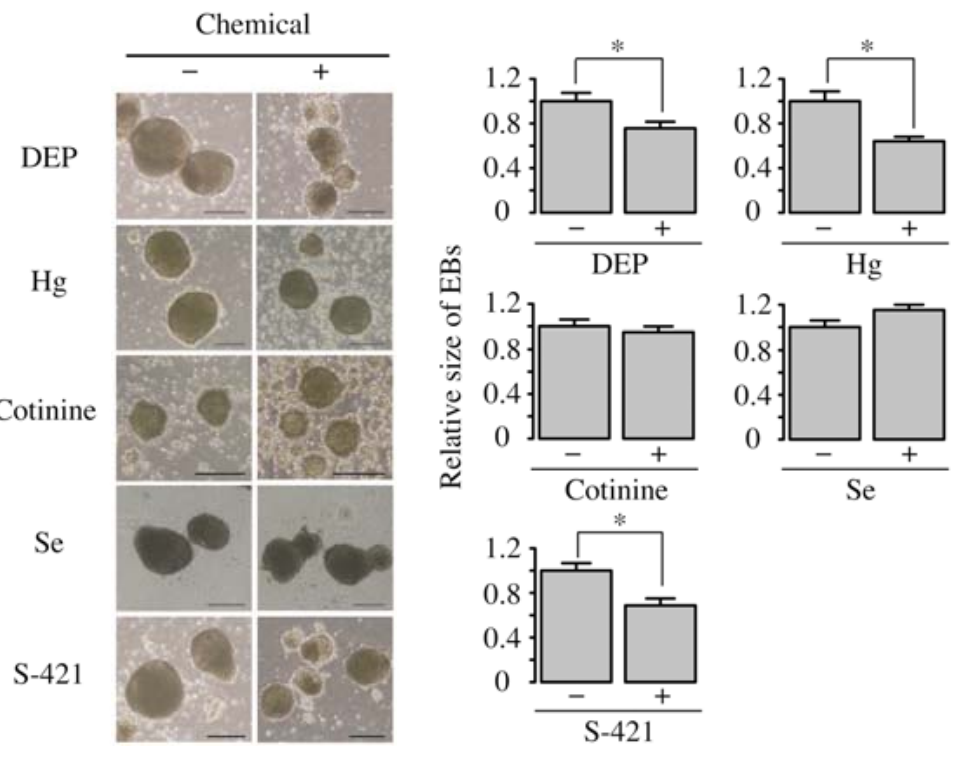

(C)

\begin{tabular}{|c|c|c|c|c|c|c|c|c|c|c|c|}
\hline & \multirow[b]{2}{*}{ Chemical } & \multirow[b]{2}{*}{$\begin{array}{c}\text { Exposure } \\
\text { to cells } \\
(\mathrm{ppb}) \\
(\times 1, \times 10)\end{array}$} & \multicolumn{2}{|c|}{ DAPI signals } & \multirow[b]{2}{*}{$\begin{array}{l}\text { (Exp. 4) } \\
\text { Size } \\
\text { of } \\
\text { EBs }\end{array}$} & & \multirow[b]{2}{*}{ Chemical } & \multirow[b]{2}{*}{$\begin{array}{c}\text { Exposure } \\
\text { to cells } \\
(\mathrm{ppb}) \\
(\times 1, \times 10)\end{array}$} & \multicolumn{2}{|c|}{ DAPI signals } & \multirow[b]{2}{*}{$\begin{array}{c}\text { (Exp. 4) } \\
\text { Size } \\
\text { of } \\
\text { EBs }\end{array}$} \\
\hline & & & $\begin{array}{l}\text { (Exp. 1) } \\
\text { Chemical } \\
\text { exposure } \\
\times 1, \times 10\end{array}$ & $\begin{array}{c}\text { (Exp. 3) } \\
\text { Removal } \\
\text { of } \\
\text { chemicals }\end{array}$ & & & & & $\begin{array}{l}\text { (Exp. 1) } \\
\text { Chemical } \\
\text { exposure } \\
\times 1, \times 10\end{array}$ & $\begin{array}{c}\text { (Exp. 3) } \\
\text { Removal } \\
\text { of } \\
\text { chemicals }\end{array}$ & \\
\hline \multirow[t]{9}{*}{\begin{tabular}{|l|}
$\mathrm{A}$ \\
\end{tabular}} & 3-PBA & $0.1,1.0$ & & ND & ND & $\mathrm{D}$ & Penta-BDE & $0.01,0.1$ & $\rightarrow \vec{a}$ & ND & ND \\
\hline & TCP & $0.1,1.0$ & $\rightarrow \quad\}$ & ND & ND & & Deca-BDE & $0.01,0.1$ & $\rightarrow$ Q & ND & ND \\
\hline & DMP & $0.1,1.0$ & $\rightarrow$ 久 & ND & ND & $\mathrm{E}$ & $\mathrm{Sn}$ & $1.0,10$ & $\rightarrow \rightarrow$ & $\mathrm{ND}^{-}$ & $\bar{N} \bar{D}$ \\
\hline & DEP & $0.1,1.0$ & そู V & 勺 & 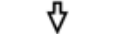 & & $\mathrm{Se}$ & 100,1000 & ND & $\rightarrow$ & $\rightarrow$ \\
\hline & DMTP & $0.1,1.0$ & $\rightarrow \rightarrow$ & ND & ND & & $\mathrm{Cd}$ & $0.1,1.0$ & $\rightarrow$ & ND & ND \\
\hline & DETP & $0.1,1.0$ & $\rightarrow \quad$ & ND & ND & & $\mathrm{Hg}$ & $1.0,10$ & 勺 & $\rightarrow$ & V \\
\hline & DMDTP & $0.1,1.0$ & $\rightarrow$ V & ND & ND & & $\underline{P}_{\ldots} \underline{z}_{-}$ & $1.0,10$ & 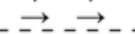 & ND_ & ND \\
\hline & DEDTP & $0.1,1.0$ & $\rightarrow \rightarrow$ & ND & ND & $\mathrm{F}$ & 2-EHA & $1.0,10$ & $\rightarrow \rightarrow$ & $\mathrm{ND}^{-}$ & $\mathrm{ND}$ \\
\hline & S-421 & $0.01,0.1$ & $\boldsymbol{A}$ & $\rightarrow$ & 乌 & & 2-EH & 10,100 & $\rightarrow$ & ND & ND \\
\hline$\sqrt{B}$ & Nicotine & 100,1000 & $\rightarrow \vec{a}$ & $\bar{N} \bar{D}$ & ND & & DCB_ & 10,100 & $\rightarrow$ & ND_ & ND \\
\hline & Cotinine & 100,1000 & 勺 & & & $G$ & DEHP & $1.2,12$ & $\rightarrow$ & ND & $\mathrm{ND}$ \\
\hline $\mathrm{C}$ & PFŌA & 10,100 & $\rightarrow \rightarrow$ & $\mathrm{ND}$ & $\mathrm{ND}$ & & MEHP & $5.0,50$ & $\rightarrow$ & ND & ND \\
\hline & PFOS & 10,100 & $\rightarrow \rightarrow$ & ND & ND & & & & & & \\
\hline
\end{tabular}

Fig. 4. 
chemicals. We examined heterochromatin in ESCs exposed to the chemicals DEP, Hg, cotinine, Se and S-421 the serum level concentrations for $48 \mathrm{~h}$ and then cultured for $48 \mathrm{~h}$ after their removal (Exp. 3 in Fig. 1). In the pretreatment of ESCs with Hg, cotinine, Se and S-421, the number of DAPI signals in the ESCs was reversed to almost the same levels as their controls (Fig. 4A, upper panel), suggesting that alteration of heterochromatin was reversible in the cells exposed to these four chemicals. In contrast, the reduced number of DAPI signals in DEP-exposed cells did not recover to the control level after removal of DEP (Fig. 4A, upper panel). In addition, the area occupied by major satellite signals also remained at the affected levels even after removal of DEP (Fig. 4A, lower panel). Thus, DEP-induced heterochromatin change was irreversible, even after $48 \mathrm{~h}$.

\section{Effects of DEP, Hg, cotinine, Se and S-421 on differentiation potentials in formation of EBs}

To test the effects of the chemicals on developmental potential, we investigated the effects of chemicals on EB formation (Exp. 4 in Fig. 1). Although exposure to cotinine and Se had no effect on EB formation judged by the sizes of EBs between chemical-exposed and control cells, in the presence of DEP, $\mathrm{Hg}$ and S-421 at a low concentration, the sizes of the EBs were significantly smaller than those of the controls (Fig. 4B).

\section{Discussion}

The assessment of environmental chemicals has usually been performed with high doses of chemicals, resulting in growth arrest in the previous studies. However, many chemicals have been detected in human samples with much lower concentrations, at which severe growth arrest and cell death are not observed. In the present study, using mouse ESCs as an in vitro model for early embryos, we demonstrated that at least five chemicals (DEP, cotinine, Hg, Se and S-421) have epimutagenic effects at the serum concentrations of maternal peripheral blood and cord blood. The majority of the chemicals (20/25) examined had no effect on heterochromatin formation at the serum level, whereas a 10 times higher or more pharmacological dose may have some effects. In addition, exposure to $\mathrm{Hg}$ and Se caused alteration of DNA methylation status at unique gene loci harboring T-DMRs, DEP showed a long-term effect and DEP, Hg and S-421 affected the developmental potentials. Thus, certain chemicals that are detected in human samples affect the epigenetic levels. A summary of the results is shown in Fig. 4C.

Of the five epimutagens, DEP-exposed ESCs did not recover from the altered heterochromatin status even after removal of the chemical, whereas the other chemicals (Hg, cotinine, Se and S-421) exhibited reversal of the number of DAPI signals after removal of the chemicals. This implies that DEP can cause long-lasting heterochromatin changes even at concentrations detected in the serum of cord blood. DEP is a metabolite of chlorpyrifos, which is a component of pesticides. Prenatal exposure to pesticides caused lasting developmental disorders such as neural dysfunction in children even after birth $[48,49]$. The EB is an in vitro model for differentiating early embryos [50], and EB formation was impaired in the presence of serum levels of DEP, Hg and S-421, which caused altered heterochromatin formation in ESCs. In particular, DEPinduced epigenetic changes are probably long lasting even at serum level concentrations. Collectively, certain chemicals such as DEP have the potential to cause epigenetic dysfunction in developing early embryos.

The genes showing disturbed DNA methylation status upon $\mathrm{Hg}$ or Se exposure have important roles in fetal development. Aebp2 is a component of the epigenetic regulator Polycomb Repression Complex 2 [51]. Prickle2 and Rnd2 are related to neural differentiation [52, 53]. This implies that the genes with various functions regulated by DNA methylation are affected in ESCs, which are thought of as an in vitro model of early embryonic cells.

The cytotoxic effects of chemicals are more severe in early stages of development than in adulthood [54, 55]. Heavy metals such as Se and Cd have been reported to cause epigenetic alteration in human cancer cell lines or fibroblasts [56, 57], although the cells were treated with high doses that were more than 10 times those of the serum level. On the other hand, human prostate cancer cell line LNCsP did not exhibit altered DNA methylation after exposure to Se for four days [58]. In the present study, $\mathrm{Hg}$ and Se at serum levels caused altered heterochromatin marks and DNA methylation changes in ESCs.

In conclusion, the method using mouse ESCs to assess the epimutagens was simple and sensitive. We demonstrated that DEP, Hg, cotinine, Se and S-421 altered epigenetic systems at serum level concentrations detected in human maternal peripheral blood and cord blood.

\section{Acknowledgments}

This work was supported by a Health Science Research Grant

Fig. 4. Reversibility of heterochromatin alteration and developmental effect of the five chemicals. A: Effect of chemicals on heterochromatin states after removal of the chemicals. ESCs were cultured with either of the chemicals (DEP, Hg, cotinine, Se and S-421) at the serum level concentrations or solvent only for $48 \mathrm{~h}$, and then culture was continued without the chemicals or solvent (control) for another $48 \mathrm{~h}$. The results are shown as a box plot. DNA-FISH analysis with a specific DNA probe for major satellite repeats in ESCs after removal of DEP. Localizations of major satellite repeats (red), DAPI-stained DNA (blue) and the merged images are shown. Scale bar $=10 \mu \mathrm{m}$. Statistical comparisons of DAPI signal numbers were performed using the Wilcoxon test. *: $\mathrm{P}<0.01$. B: Impaired EB formation by chemical exposure at the serum level concentrations. ESCs induced differentiation into EBs in the presence of one of the five chemicals (DEP, Hg, cotinine, Se and S-421). The sizes of the EBs exposed to chemicals at the serum level concentrations were measured as their areas by ImageJ. The average and SE were calculated for the areas of the EBs. Relative areas in chemical-exposed EBs were normalized to average areas of solvent-exposed control EBs. Experiments were performed at least twice independently for each chemical. -: Solvent only. +: Exposure to chemicals at the serum level concentrations. Scale bar $=250 \mu \mathrm{m}$. Statistical comparisons of the areas of EBs were performed using the Student's $t$-test. *: P<0.01. C: Summary of heterochromatin analysis based on the DAPI staining (Exp. 1, 3 in Fig 1) and EB formation (Exp. 4 in Fig 1). $\uparrow:$ Increase. $\downarrow$ : Decrease. $\rightarrow$ : No change of DAPI signal number or size of EBs compared with solvent-treated controls. ND: Not determined. 
from the Ministry of Health, Labour and Welfare, Japan (to TM) and a Grant-in Aid for Scientific Research(S) from the Ministry of Education, Culture, Sports, Science and Technology of Japan (21221008 to KS). The authors claim no competing financial interests.

\section{References}

1. Al-Saleh I, Shinwari N, Mashhour A, Mohamed GE, Rabah A. Heavy metals (lead, cadmium and mercury) in maternal, cord blood and placenta of healthy women. Int J Hyg Environ Health (in press).

2. Inoue K, Okada F, Ito R, Kato S, Sasaki S, Nakajima S, Uno A, Saijo Y, Sata F, Yoshimura Y, Kishi R, Nakazawa H. Perfluorooctane sulfonate (PFOS) and related perfluorinated compounds in human maternal and cord blood samples: assessment of PFOS exposure in a susceptible population during pregnancy. Environ Health Perspect 2004; 112: 1204-1207.

3. Okano K, Hinohara M, Iwasaki Y, Ito R, Saito K, Izumi S, Makino T, Nakazawa H. Determination of nicotine and cotinine in human serum for evaluation of tobacco smoke exposure by hydrophilic interaction chromatography/mass spectrometry. Bunseki Kagaku 2007; 56: 785-790 (In Japanese).

4. Takatori S, Kitagawa Y, Kitagawa M, Nakazawa H, Hori S. Determination of di (2ethylhexyl) phthalate and mono (2-ethylhexyl) phthalate in human serum using liquid chromatography-tandem mass spectrometry. J Chromatogr B Analyt Technol Biomed Life Sci 2004; 804: 397-401.

5. Whyatt RM, Camann DE, Kinney PL, Reyes A, Ramirez J, Dietrich J, Diaz D, Holmes D, Perera FP. Residential pesticide use during pregnancy among a cohort of urban minority women. Environ Health Perspect 2002; 110: 507-514.

6. Zhang H, Feng X, Larssen T, Qiu G, Vogt RD. In inland China, rice, rather than fish, is the major pathway for methylmercury exposure. Environ Health Perspect 2010; 118: 1183-1188.

7. Jaddoe VW, Troe EJ, Hofman A, Mackenbach JP, Moll HA, Steegers EA, Witteman JC. Active and passive maternal smoking during pregnancy and the risks of low birthweight and preterm birth: the Generation R Study. Paediatr Perinat Epidemiol 2008; 22: $162-171$.

8. Washino N, Saijo Y, Sasaki S, Kato S, Ban S, Konishi K, Ito R, Nakata A, Iwasaki Y, Saito K, Nakazawa H, Kishi R. Correlations between prenatal exposure to perfluorinated chemicals and reduced fetal growth. Environ Health Perspect 2009; 117: 660-667.

9. Whyatt RM, Rauh V, Barr DB, Camann DE, Andrews HF, Garfinkel R, Hoepner LA, Diaz D, Dietrich J, Reyes A, Tang D, Kinney PL, Perera FP. Prenatal insecticide exposures and birth weight and length among an urban minority cohort. Environ Health Perspect 2004; 112: 1125-1132.

10. Zhu M, Fitzgerald EF, Gelberg KH, Lin S, Druschel CM. Maternal low-level lead exposure and fetal growth. Environ Health Perspect 2010; 118: 1471-1475.

11. Ananth CV, Smulian JC, Vintzileos AM. Incidence of placental abruption in relation to cigarette smoking and hypertensive disorders during pregnancy: a meta-analysis of observational studies. Obstet Gynecol 1999; 93: 622-628.

12. Kippler M, Hoque AM, Raquib R, Ohrvik H, Ekström EC, Vahter M. Accumulation of cadmium in human placenta interacts with the transport of micronutrients to the fetus. Toxicol Lett 2010; 192: 162-168.

13. Llanos MN, Ronco AM. Fetal growth restriction is related to placental levels of cadmium, lead and arsenic but not with antioxidant activities. Reprod Toxicol 2009; 27: 8892.

14. Todaka E, Sakurai K, Fukata H, Miyagawa H, Uzuki M, Omori M, Osada H, Ikezuki Y, Tsutsumi O, Iguchi T, Mori C. Fetal exposure to phytoestrogens-the difference in phytoestrogen status between mother and fetus. Environ Res 2005; 99: 195-203.

15. Edwards TM, Myers JP. Environmental exposures and gene regulation in disease etiology. Environ Health Perspect 2007; 115: 1264-1270.

16. Wade PA, Archer TK. Epigenetics: environmental instructions for the genome. Environ Health Perspect 2006; 114: A140-A141.

17. Golob JL, Paige SL, Muskheli V, Pabon L, Murry CE. Chromatin remodeling during mouse and human embryonic stem cell differentiation. Dev Dyn 2008; 237: 1389-1398.

18. Lieb JD, Beck S, Bulyk ML, Farnham P, Hattori N, Henikoff S, Liu XS, Okumura K, Shiota K, Ushijima T, Greally JM. Applying whole-genome studies of epigenetic regulation to study human disease. Cytogenet Genome Res 2006; 114: 1-15.

19. Shiota K. DNA methylation profiles of CpG islands for cellular differentiation and development in mammals. Cytogenet Genome Res 2004; 105: 325-334.

20. Ikegami K, Ohgane J, Tanaka S, Yagi S, Shiota K. Interplay between DNA methylation, histone modification and chromatin remodeling in stem cells and during development. Int J Dev Biol 2009; 53: 203-214.

21. Lachner M, O'Sullivan RJ, Jenuwein T. An epigenetic road map for histone lysine methylation. J Cell Sci 2003; 116: 2117-2124

22. $\mathrm{Ng} \mathrm{HH}$, Bird A. DNA methylation and chromatin modification. Curr Opin Genet Deo 1999; 9: 158-163.

23. Vissel B, Choo KH. Mouse major (gamma) satellite DNA is highly conserved and organized into extremely long tandem arrays: implications for recombination between nonhomologous chromosomes. Genomics 1989; 5: 407-414.

24. Sato S, Yagi S, Arai Y, Hirabayashi K, Hattori N, Iwatani M, Okita K, Ohgane J Tanaka S, Wakayama T, Yamanaka S, Shiota K. Genome-wide DNA methylation profile of tissue-dependent and differentially methylated regions (T-DMRs) residing in mouse pluripotent stem cells. Genes Cells 2010; 15: 607-618.

25. Shiota K, Kogo Y, Ohgane J, Imamura T, Urano A, Nishino K, Tanaka S, Hattori N Epigenetic marks by DNA methylation specific to stem, germ and somatic cells in mice. Genes Cells 2002; 7: 961-969.

26. Yagi S, Hirabayashi K, Sato S, Li W, Takahashi Y, Hirakawa T, Wu G, Hattori N, Hattori N, Ohgane J, Tanaka S, Liu XS, Shiota K. DNA methylation profile of tissuedependent and differentially methylated regions (T-DMRs) in mouse promoter regions demonstrating tissue-specific gene expression. Genome Res 2008; 18: 1969 1978.

27. Sakamoto H, Suzuki M, Abe T, Hosoyama T, Himeno E, Tanaka S, Greally JM, Hat tori N, Yagi S, Shiota K. Cell type-specific methylation profiles occurring disproportionately in CpG-less regions that delineate developmental similarity. Genes Cells 2007 12: 1123-1132.

28. Muramoto H, Yagi S, Hirabayashi K, Sato S, Ohgane J, Tanaka S, Shiota K. Enrichment of short interspersed transposable elements to embryonic stem cell-specific hypomethylated gene regions. Genes Cells 2010; 15: 855-865.

29. Holliday R. The inheritance of epigenetic defects. Science 1987; 238: 163-170.

30. Holliday R, Ho T. DNA methylation and epigenetic inheritance. Methods 2002; 27: 179-183.

31. Taddei A, Maison C, Roche D, Almouzni G. Reversible disruption of pericentric heterochromatin and centromere function by inhibiting deacetylases. Nat Cell Biol 2001; 3 $114-120$

32. Iwatani M, Ikegami K, Kremenska Y, Hattori N, Tanaka S, Yagi S, Shiota K. Dimethyl sulfoxide has an impact on epigenetic profile in mouse embryoid body. Stem Cells 2006; 24: 2549-2556

33. Chen H, Ke Q, Kluz T, Yan Y, Costa M. Nickel ions increase histone H3 lysine 9 dimethylation and induce transgene silencing. Mol Cell Biol 2006; 26: 3728-3737.

34. Iwasaki Y, Goto M, Mochizuki K, Terayama E, Ito R, Saito K, Sugino N, Makino T, Nakazawa $\mathrm{H}$. Development and validation of a hydrophilic interaction chromatography-tandem mass spectrometry for quantification of nicotine and its metabolites in human maternal and cord sera. Biomed Chromatogr (in press).

35. Nakata H, Nakata A, Okada F, Ito R, Inoue K, Saito K, Nakazawa H. Development of online solid-phase extraction-HPLC/MS/MS method for the determination of perfluorochemicals in human plasma. Bunseki Kagaku 2005; 54: 877-884 (In Japanese).

36. Akutsu K, Takatori S, Nozawa S, Yoshiike M, Nakazawa H, Hayakawa K, Makino T, Iwamoto T. Polybrominated diphenyl ethers in human serum and sperm quality. Bull Environ Contam Toxicol 2008; 80: 345-350.

37. Berman T, Hochner-Celnikier D, Barr DB, Needham LL, Amitai Y, Wormser U, Richter E. Pesticide exposure among pregnant women in Jerusalem, Israel: results of a pilot study. Environ Int 2011; 37: 198-203.

38. Takasuga T, Senthilkumar K, Takemori H, Ohi E, Tsuji H, Nagayama J. Impact of fermented brown rice with Aspergillus oryzae (FEBRA) intake and concentrations of polybrominated diphenyl ethers (PBDEs) in blood of humans from Japan. Chemosphere 2004; 57: 795-811.

39. Baker SE, Olsson AO, Barr OD. Isotope dilution high-performance liquid chromatog raphy-tandem mass spectrometry method for quantifying urinary metabolites of synthetic pyrethroid insecticides. Arch Environ Contam Toxicol 2004; 46: 281-288.

40. Olsson AO, Baker SE, Nguyen JV, Romanoff LC, Udunka SO, Walker RD, Flemmen KL, Barr DB. A liquid chromatography-tandem mass spectrometry multiresidue method for quantification of specific metabolites of organophosphorus pesticides, synthetic pyrethroids, selected herbicides, and deet in human urine. Anal Chem 2004 76: 2453-2461.

41. Kakimoto K, Akutsu K, Konishi Y, Tanaka Y. Time trend of hexabromocyclododecane in the breast milk of Japanese women. Chemosphere 2007; 71: 1110-1114.

42. Ueyama J, Saito I, Kamijima M, Nakajima T, Gotoh M, Suzuki T, Shibata E, Kondo T, Takagi K, Miyamoto K, Takamatsu J, Hasegawa T, Takagi K. Simultaneous determination of urinary dialkylphosphate metabolites of organophosphorus pesticides using gas chromatography-mass spectrometry. J Chromatogr B Analyt Technol Biomed Life Sci 2006; 832: 58-66.

43. Razagui IB, Ghribi I. Maternal and neonatal scalp hair concentrations of zinc, copper, cadmium, and lead: relationship to some lifestyle factors. Biol Trace Elem Res 2005; 106 $1-28$.

44. Kondo F, Ikai Y, Goto T, Ito Y, Oka H, Nakazawa H, Odajima Y, Kamijima M, Shi- 
bata E, Torii S, Miyazaki Y. Serum levels of volatile organic compounds in patients with sick building syndrome. Bull Environ Contam Toxicol 2006; 77: 331-337.

45. Lehnertz B, Ueda Y, Derijck AA, Braunschweig U, Perez-Burgos L, Kubicek S, Chen T, Li E, Jenuwein T. Peters AH. Suv39h-mediated histone H3 lysine 9 methylation directs DNA methylation to major satellite repeats at pericentric heterochromatin. Curr Biol 2003; 13: 1192-1200.

46. Senda S, Blanche S, Costagliola D, Cibert C, Nigon F, Firtion G, Floch C, Parat S, Viegas-Péquignot $\mathrm{E}$. Altered heterochromatin organization after perinatal exposure to zidovudine. Antivir Ther 2007; 12: 179-187.

47. Xiong Z, Laird PW. COBRA: a sensitive and quantitative DNA methylation assay. Nucleic Acids Res 1997; 25: 2532-2534.

48. Eskenazi B, Marks AR, Bradman A, Harley K, Barr DB, Johnson C, Morga N, Jewell NP. Organophosphate pesticide exposure and neurodevelopment in young MexicanAmerican children. Environ Health Perspect 2007; 115: 792-798.

49. Harari R, Julvez J, Murata K, Barr D, Bellinger DC, Debes F, Grandjean P. Neurobehavioral deficits and increased blood pressure in school-age children prenatally exposed to pesticides. Environ Health Perspect 2010; 118: 890-896.

50. O'Shea KS. Embryonic stem cell models of development. Anat Rec 1999; 257: $32-41$.

51. Kim H, Kang K, Kim J. AEBP2 as a potential targeting protein for Polycomb Repression Complex PRC2. Nucleic Acids Res 2009; 37: 2940-2950.

52. Heng JI, Nguyen L, Castro DS, Zimmer C, Wildner H, Armant O, Skowronska-
Krawczyk D, Bedogni F, Matter JM, Hevner R, Guillemot F. Neurogenin 2 controls cortical neuron migration through regulation of Rnd2. Nature 2008; 455: 114-118.

53. Okuda H, Miyata S, Mori Y, Tohyama M. Mouse Prickle1 and Prickle2 are expressed in postmitotic neurons and promote neurite outgrowth. FEBS Lett 2007; 581: 47544760 .

54. Benke GM, Murphy SD. The influence of age on the toxicity and metabolism of methyl parathion and parathion in male and female rats. Toxicol Appl Pharmacol 1975 31: 254-269.

55. Chakraborti TK, Farrar JD, Pope CN. Comparative neurochemical and neurobehavioral effects of repeated chlorpyrifos exposures in young and adult rats. Pharmacol Biochem Behav 1993; 46: 219-224

56. Jiang G, Xu L, Song S, Zhu C, Wu Q, Zhang L, Wu L. Effects of long-term low-dose cadmium exposure on genomic DNA methylation in human embryo lung fibroblast cells. Toxicology 2008; 244: 49-55.

57. Xiang N, Zhao R, Song G, Zhong W. Selenite reactivates silenced genes by modifying DNA methylation and histones in prostate cancer cells. Carcinogenesis 2008; 29: 2175 2181.

58. Ramachandran K, Navarro L, Gordian E, Das PM, Singal R. Methylation-mediated silencing of genes is not altered by selenium treatment of prostate cancer cells. Anticancer Res 2007; 27: 921-926. 